\title{
Reinvestigation of lactose intolerant children: lack of correlation between continuing lactose intolerance and small intestinal morphology, disaccharidase activity, and lactose tolerance tests
}

\author{
MARY HARRISON AND J. A. WALKER-SMITH \\ From the Academic Department of Child Health, The Medical College of St. Bartholomew's Hospital, \\ and The London Hospital Medical College, Queen Elizabeth Hospital for Children, London
}

SUMMARY Thirty children on a lactose-free diet aged from 2-38 months who had previously been diagnosed as having secondary lactose intolerance were reinvestigated on 32 occasions by an oral lactose tolerance test, small intestinal biopsy, and measurement of disaccharidase activity in order to detect the presence of continuing lactose intolerance before reintroduction of milk. No correlation was found between continuing lactose intolerance, as diagnosed by the development of watery stools containing excess reducing substances after an oral load of lactose, and maximum blood glucose rise during a lactose tolerance test, lactase levels, and small intestinal morphology.

Lactose intolerance is the clinical syndrome characterised in infants and children by the development of watery diarrhoea when lactose is ingested. It may be primary, due to an inherited enzyme defect, or it may be secondary to damage to the small intestinal mucosa, which results in reduction in the level of disaccharidases. The clinical manifestations of lactose intolerance may be influenced by a number of other factors such as the dose of lactose ingested, gastrointestinal motility, intestinal length, and the biochemical capacities of the intestinal flora (Townley, 1966).

Some workers have used the term lactose malabsorption when there is an abnormal lactose tolerance test (LTT) or reduced disaccharidase activity in the absence of clinical lactose intolerance (Auricchio et al., 1965), but for the clinician it is the presence of clinical intolerance that is of importance, as it involves a management decision, rather than the demonstration of some dysfunction of lactose digestion and absorption which is not causing a clinical problem.

Milk intolerance after acute gastroenteritis may be due to secondary lactose intolerance (Burke et al., 1965) and/or to cow's milk protein intolerance (Harrison et al., 1976). After a period on a milk free diet, and before a cow's milk challenge, it is, therefore, important to know whether lactose intolerance Received for publication 12 August 1976 is still present, and also whether the small intestinal mucosa is normal.

A number of investigations have been recommended in order to make the diagnosis of lactose intolerance, including an oral lactose tolerance or loading test, stool pH, measurement of stool reducing substances, paper chromatography of the stool for sugar and estimation of small intestinal lactase activity, as well as the clinical response to restriction of the offending sugar. The opportunity presented by reinvestigation of children on a lactose free diet has been taken critically to evaluate some of these investigations, and to relate these to clinical lactose intolerance.

\section{Methods}

PATIENTS

The study consisted of all those children on a lactose free, milk free diet admitted to the Queen Elizabeth Hospital for Children, London, in the three year period from January 1973, for reinvestigation by LTT, small intestinal biopsy, and measurement of disaccharidase activity for the presence of continuing lactose intolerance during a single admission. Thirty children were reinvestigated on 32 occasions. They had all previously been diagnosed as having secondary lactose intolerance on the basis of the presence of watery diarrhoea containing 
$0.5-2 \%$ reducing substances while on a lactose containing diet, with clinical response to a lactose free diet. In 27 cases paper chromatography of the stools was performed and confirmed the diagnosis of lactose intolerance. The cause of their secondary lactose intolerance is shown in Table 1.

Table 1 Cause of secondary lactose intolerance

\begin{tabular}{lc}
\hline Diagnosis & Number \\
\hline Cow's milk protein intolerance & 17 \\
Gastroenteritis & 11 \\
Multiple food intolerance & 1 \\
Ileal atresia (postoperative) & 1 \\
\hline
\end{tabular}

LACTOSE TOLERANCE TEST

An oral load of $2 \mathrm{~g}$ lactose/ $\mathrm{kg}$ body weight was given after a fast of not less than eight hours. Capillary blood was taken by finger prick at 0,30 , $60,90,120$ minutes for blood glucose estimation. All stools passed for 24 hours afterwards were recorded and tested for reducing substances using Clinitest tablets. In the majority of cases paper chromatography of the stool for sugar was performed if reducing substances were detected. A rise of blood glucose of less than $1.12 \mathrm{~mm} / 1(20 \mathrm{mg} \%)$ above the fasting level was considered to be 'flat'. A rise of between $1.12 \mathrm{~mm} / 1$ and $1.68 \mathrm{~mm} / 1(30$ $\mathrm{mg} \%$ ) was considered to be borderline, and a rise of greater than $1.68 \mathrm{~mm} / \mathrm{l}$ to be normal.

\section{SMALL INTESTINAL BIOPSY}

A paediatric modification of the Crosby capsule was used. The child was fasted and sedated. The capsule was introduced and screened into position, the specimen being taken from close to the fourth part of the duodenum, at the duodenojejunal flexure or the first loop of the jejunum. The biopsy was examined and photographed under the dissecting microscope, and subsequently by light microscopy. The histological findings were graded as follows:

$\mathbf{N}=$ Normal.

$\pm=$ Minimal or doubtful lesion.

$+=$ Short wide villi, usually with normal surface epithelium, increased cells in lamina propria and rather long crypts.

$++=$ Thickened ridges, usually with normal surface epithelium, moderate increase of cells in lamina propria, elongated crypts.

$++t=$ Flat surface covered by abnormal epithelium with excess cells in lamina propria and elongated crypts.

ESTIMATION OF DISACCHARIDASE ACTIVITIES Mucosal disaccharidase activities were measured by the method of Burgess et al. (1964). Specimens were deep frozen immediately and the estimation made within one week. The lower limit of normal for lactase levels in the duodenum, the duodenojejunal flexure, and the jejunum were $0 \cdot 2,2 \cdot 0$, and $2 \cdot 7 \mu \mathrm{mol}$ disaccharide hydrolysed per minute per gram wet weight of mucosa respectively (Burgess et al., 1964).

\section{Results}

There were 24 males $(69 \%)$ and eight females ( $23 \%)$ in the study. The mean age was 10.4 months, range 2-38 months.

Four children developed profuse diarrhoea with 0.5 to $2 \%$ reducing substances in the stools and the pattern of lactose malabsorption on stool chromatography after a LTT, a clinical diagnosis of continuing lactose intolerance was made in these children. The data concerning them is given in Table 2. There was no correlation between this clinical diagnosis, the maximum rise in blood glucose during the LTT, the morphology of the small intestinal mucosa, or the level of lactase activity.

The correlation between the maximum blood glucose rise during LTT and the development of symptoms after an oral lactose load, lactase levels, and the results of small intestinal biopsy are shown in Table 3. Clinical lactose intolerance occurred whether the rise in blood glucose was 'flat', borderline or, normal-that is, there was no correlation between maximum rise in blood glucose and clinical lactose intolerance, nor indeed was there any constant relationship between this rise and the presence of reduced lactase activity or the state of the small intestinal mucosa.

Table 4 shows the relationship between disaccharidase activities and the small intestinal morphology, the rise in blood glucose, and clinical lactose intolerance. Somewhat surprisingly, lactase activities were normal in all those showing clinical lactose intolerance and most children with a 'flat' rise had normal lactase levels on biopsy.

Table 5 shows the relationship between small intestinal morphology and the lactase activity, maximum rise in blood glucose, and symptomatology. Continuing lactose intolerance was found to occur irrespective of whether the morphology of the small intestine was normal or abnormal, and reduced lactase levels appeared to be unrelated to small intestinal morphology.

Table 6 indicates the disaccharidase results in more detail for those children with ++ morphological abnormality but normal lactase activity.

\section{Discussion}

It has been widely established that the demonstra- 
Table 2 Data of children with clinical evidence of lactose intolerance

\begin{tabular}{|c|c|c|c|c|c|c|c|c|}
\hline Patient & $\operatorname{Sex}$ & $\begin{array}{l}\text { Age } \\
\text { (months) }\end{array}$ & $\begin{array}{l}\text { Maximum rise } \\
\text { in blood glucose } \\
(\mathrm{mm} / \mathrm{l})\end{array}$ & $\begin{array}{l}\text { Watery } \\
\text { diarrhoea }\end{array}$ & $\begin{array}{l}\text { Stool reducing } \\
\text { substances } \\
(0.5-2 \%)\end{array}$ & $\begin{array}{l}\text { Stool } \\
\text { chromatography }\end{array}$ & $\begin{array}{l}\text { Lactase } \\
\text { activity }\end{array}$ & $\begin{array}{l}\text { Small intestinal } \\
\text { biopsy }\end{array}$ \\
\hline $\begin{array}{l}1 \\
2 \\
3 \\
4\end{array}$ & $\begin{array}{l}\mathbf{M} \\
\mathbf{M} \\
\mathbf{M} \\
\mathbf{M}\end{array}$ & $\begin{array}{r}5 \\
6 \\
8 \\
17\end{array}$ & $\begin{array}{l}2.70 \\
1.46 \\
1.68 \\
1.01\end{array}$ & $\begin{array}{l}+ \\
+ \\
+ \\
+\end{array}$ & $\begin{array}{l}+ \\
+ \\
+ \\
+\end{array}$ & $\begin{array}{l}+ \\
+ \\
+ \\
+\end{array}$ & $\begin{array}{l}\mathbf{N} \\
\mathbf{N} \\
\mathbf{N} \\
\mathbf{N}\end{array}$ & $\begin{array}{l}\mathbf{N} \\
\mathbf{N} \\
++ \\
\pm\end{array}$ \\
\hline
\end{tabular}

Table 3 Correlation between lactose tolerance tests, and the development of symptoms, small intestinal biopsy and lactase activities

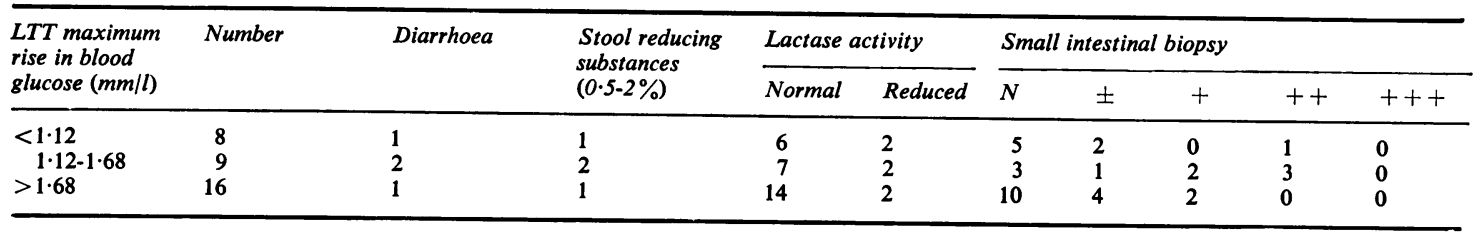

Table 4 Correlation between lactase activity and small intestinal morphology, lactose tolerance test, and clinical lactose intolerance

\begin{tabular}{|c|c|c|c|c|c|c|c|c|c|}
\hline \multirow[t]{3}{*}{$\begin{array}{l}\text { Lactase activity } \\
(\mu \mathrm{m} / \mathrm{min} / \mathrm{g})\end{array}$} & \multirow[t]{3}{*}{ Number } & \multicolumn{4}{|c|}{ Small intestinal biopsy } & \multirow{2}{*}{\multicolumn{3}{|c|}{$\begin{array}{l}\text { LTT maximum blood glucose } \\
\text { rise }(\mathrm{mm} / \mathrm{l})\end{array}$}} & \multirow{3}{*}{$\begin{array}{l}\text { Clinical evidence of } \\
\text { lactose intolerance }\end{array}$} \\
\hline & & \multirow[t]{2}{*}{$N$} & \multirow[t]{2}{*}{ \pm} & \multirow[t]{2}{*}{+} & \multirow{2}{*}{++} & & & & \\
\hline & & & & & & $<1 \cdot 12$ & $1 \cdot 12-1 \cdot 68$ & $>1.68$ & \\
\hline $\begin{array}{l}\text { Normal } \\
\text { Reduced }\end{array}$ & $\begin{array}{r}25 \\
7\end{array}$ & $\begin{array}{r}15 \\
3\end{array}$ & $\begin{array}{l}4 \\
3\end{array}$ & $\begin{array}{l}3 \\
1\end{array}$ & $\begin{array}{l}3 \\
0\end{array}$ & $\begin{array}{l}5 \\
3\end{array}$ & $\begin{array}{l}6 \\
2\end{array}$ & $\begin{array}{r}14 \\
2\end{array}$ & $\begin{array}{l}4 \\
0\end{array}$ \\
\hline
\end{tabular}

Table 5 Correlation between small intestinal biopsy and lactase activity, lactose tolerance tests, and lactose intolerance

\begin{tabular}{|c|c|c|c|c|c|c|c|}
\hline \multirow[t]{3}{*}{ Biopsy } & \multirow[t]{3}{*}{ Number } & \multicolumn{2}{|c|}{ Lactase activity (no.) } & \multirow{2}{*}{\multicolumn{3}{|c|}{$\begin{array}{l}\text { LTT maximum rise in blood glucose } \\
(\mathrm{mm} / \mathrm{l})\end{array}$}} & \multirow{3}{*}{$\begin{array}{l}\text { Clinical evidence of } \\
\text { lactose intolerance }\end{array}$} \\
\hline & & \multirow{2}{*}{ Normal } & \multirow{2}{*}{ Reduced } & & & & \\
\hline & & & & $<1 \cdot 12$ & $1 \cdot 12-1 \cdot 68$ & $>1.68$ & \\
\hline $\begin{array}{l}\mathbf{N} \\
\pm \\
+ \\
++\end{array}$ & $\begin{array}{r}18 \\
7 \\
4 \\
4\end{array}$ & $\begin{array}{r}15 \\
4 \\
3 \\
4\end{array}$ & $\begin{array}{l}3 \\
3 \\
1 \\
0\end{array}$ & $\begin{array}{l}5 \\
2 \\
0 \\
1\end{array}$ & $\begin{array}{l}3 \\
1 \\
2 \\
3\end{array}$ & $\begin{array}{r}10 \\
4 \\
2 \\
0\end{array}$ & $\begin{array}{l}2 \\
1 \\
0 \\
1\end{array}$ \\
\hline
\end{tabular}

Table 6 Disaccharidase activity in four children with ++ morphological abnormality

\begin{tabular}{|c|c|c|c|c|c|c|}
\hline \multirow{2}{*}{$\begin{array}{l}\text { Site of biopsy } \\
\text { 4th part duodenum } \\
\text { Duodenojejunal flexure } \\
\text { Duodenojejunal flexure } \\
\text { 1st part jejunum }\end{array}$} & \multicolumn{2}{|c|}{ Lactase* } & \multicolumn{2}{|c|}{ Sucrase* } & \multicolumn{2}{|c|}{ Maltase* } \\
\hline & $\begin{array}{l}0 \cdot 5 \\
3 \cdot 7 \\
2 \cdot 2 \\
2 \cdot 8\end{array}$ & $\begin{array}{l}(0 \cdot 2-3 \cdot 5) \\
(2 \cdot 0-16 \cdot 2) \\
(2 \cdot 0-16 \cdot 2) \\
(2 \cdot 7-9 \cdot 3)\end{array}$ & $\begin{array}{l}2 \cdot 1 \\
8 \cdot 6 \\
3 \cdot 5 \\
3 \cdot 4\end{array}$ & $\begin{array}{l}(2 \cdot 2-8 \cdot 7) \\
(3 \cdot 1-20 \cdot 2) \\
(3 \cdot 1-20 \cdot 2) \\
(1 \cdot 3-5 \cdot 1)\end{array}$ & $\begin{array}{r}6 \cdot 7 \\
22 \cdot 6 \\
16 \cdot 0 \\
19 \cdot 8\end{array}$ & $\begin{array}{l}(7 \cdot 5-25 \cdot 4) \\
(14 \cdot 6-77) \\
(14 \cdot 6-77) \\
(19 \cdot 2-48 \cdot 4)\end{array}$ \\
\hline
\end{tabular}

*Normal range in parentheses.

tion of excess reducing substances in the stool from infants being fed with a lactose containing diet is the most reliable way to diagnose clinical lactose intolerance in infancy, the diarrhoea rapidly responding to the elimination of lactose (Kerry and Anderson, 1964; Soeparto et al., 1972). Similarly, the return of diarrhoea after an oral load of lactose given to a child who is having a lactose free diet is a reliable way to diagnose continuing clinical lactose intolerance (Anderson and Burke, 1975).

The difficulty of ensuring adequate stool collection after an oral lactose load has led some observers to continue to use maximum rise in blood glucose after a LTT as an indicator of lactose intolerance, despite the fact that there is a high incidence of false positive results (Newcomer and McGill, 1966). This 
may be due to factors such as delayed gastric emptying, and altered handling of glucose after absorption, particularly in malnourished children (Holdsworth, 1969). An intraduodenal lactose tolerance test has recently been shown in children to correlate well with lactase activity, and also to be a better indicator of lactose intolerance (Krasilnikoff et al., 1975).

In this study we found both false positive resultsthe maximum rise in blood glucose being less than $1.12 \mathrm{~mm} / \mathrm{l}$ in children with no clinical evidence of lactose intolerance - and also false negative resultsthe rise in blood glucose being normal in children with clinical lactose intolerance. We, therefore, go further than Krasilnikoff and his colleagues, and suggest that routine estimation of blood glucose after an oral lactose load is not a useful measurement in children, and should be abandoned.

Our study has also shown that there is not only a negative correlation between continuing clinical lactose intolerance and maximum rise in blood glucose after a LTT, but also with small intestinal mucosal morphology and lactase activity.

The lack of correlation between clinical lactose intolerance and both the severity of mucosal damage and lactase depression is perhaps, not surprising, as it is well known that most children with coeliac disease who have a 'flat' mucosa and very low lactase levels, do not have clinical lactose intolerance. Gastroenteritis or cow's milk protein intolerance was the cause of the enteropathy in most of the children studied. Both of these give rise to a patchy lesion involving varying lengths of the small intestine (Walker-Smith, 1972; Kilby, 1976). It is, therefore, probable that, although the enzyme activity as measured was found to be low, there was, nevertheless, sufficient activity in the gut as a whole for normal lactose absorption to occur. Conversely, the lactase activity as measured in those children with symptoms of lactose intolerance was normal, but presumably the total activity was not sufficient to prevent lactose intolerance. Normal lactase levels in lactose intolerant subjects have previously been demonstrated by Dunphy et al. (1965), and McMichael (1972) has shown that in patients with normal lactase activity there is no correlation between lactase activity and maximum blood glucose rise after an oral load.

It is perhaps more surprising that there was no correlation between the severity of the mucosal damage and lactase levels. Of course, in the absence of electron microscopy, it is not possible to be certain that the epithelium of the mucosa was completely normal morphologically in the three children who had normal histology, despite reduced lactase levels. Barnes and Townley (1973) reported similar findings in biopsies from children with acute gastroenteritis, and they also showed that acute disaccharidase depression did not correlate with subsequent persisting lactose intolerance. It is also known that lactase activities vary according to the site within the small intestine from which they are taken, the levels being higher in the jejunum than in the duodenum (Dahlqvist, 1964). However, even if the site of the biopsy had been mistaken, this could have accounted for only two of the four children with apparently normal disaccharidase levels and ++ morphological abnormality.

On the basis of this study it is concluded that there is a negative correlation on the one hand between the maximum rise in blood glucose during LTT, the small intestinal morphology and lactase activity, and on the other hand with continuing lactose intolerance.

We are grateful to Dr N. E. France for interpretation of small intestinal biopsies, and to $\mathrm{Mr} \mathrm{V}$. Oberholzer for estimation of disaccharidase activities and blood glucose levels.

\section{References}

Anderson, C. M., and Burke, V. (1975). Paediatric Gastroenterology, p. 213. Blackwell: Oxford.

Auricchio, S., Rubino, A., Prader, A., Rey, J., Ros, J., Frézal, J., and Davidson, M. (1965). Intestinal glycosidase activities in congenital malabsorption of disaccharides. Journal of Pediatrics, 66, 555-564.

Barnes, G. L., and Townley, R. R. W. (1973). Duodenal mucosal damage in 31 infants with gastroenteritis. Archives of Disease in Childhood, 48, 343-349.

Burgess, E. A., Levin, B., Mahalanabis, D., and Tonge, R. E. (1964). Hereditary sucrose intolerance: levels of sucrase activity in jejunal mucosa. Archives of Disease in Childhood, 39, 431-443.

Burke, V., Kerry, K. R., and Anderson, C. M. (1965). The relationship of dietary lactose to refractory diarrhoea in infancy. Australian Paediatric Journal, 1, 147-160.

Dahlqvist, A. (1964). Intestinal disaccharidases. In Disorders due to Intestinal Defective Carbohydrate Digestion and Absorption, p. 5. Edited by P. Durand. Il Pensiero Scientifico: Rome.

Dunphy, J. V., Littman, A., Hammond, J. B., Forstner, G., Dahlqvist, A., and Crane, R. K. (1965). Intestinal lactase deficit in adults. Gastroenterology, 49, 12-21.

Harrison, B. M., Kilby, A., Walker-Smith, J. A., France, N. E., and Wood, C. B. S. (1976). Cow's milk protein intolerance: a possible association with gastroenteritis, lactose intolerance and IgA deficiency. British Medical Journal, 1, 1501.

Holdsworth, C. D. (1969). The gut and oral glucose tolerance. Gut, 10, 422-427.

Kerry, K. R., and Anderson, C. M. (1964). A ward test for sugar in faeces. Lancet, 1, 981-982.

Kilby, A. (1976). Paediatric small intestinal biopsy capsule with two ports. Gut, 17, 158-159.

Krasilnikoff, P. A., Gudmand-Høyer, E., and Moltke, H. H. (1975). Diagnostic value of disaccharide tolerance tests in children. Acta Paediatrica Scandinavica, 64, 693-698.

McMichael, H. B. (1972). The irrelevancies of disaccharidase 
assays. Acta-Hepato-Gastroenterologica, 19, 281-290.

Newcomer, A. D., and McGill, D. B. (1966). Lactose tolerance tests in adults with normal lactase activity. Gastroenterology, 50, 340-346.

Soeparto, P., Stobo, E. A., and Walker-Smith, J. A. (1972). Role of chemical examination of the stool in diagnosis of sugar malabsorption in children. Archives of Disease in
Childhood, 47, 56-61.

Townley, R. R. W. (1966). Disaccharidase deficiency in infancy and childhood. Pediatrics, 38, 127-141.

Walker-Smith, J. A. (1972). Uniformity of dissecting microscope appearances in proximal small intestine. Gut, 13, 17-20. 